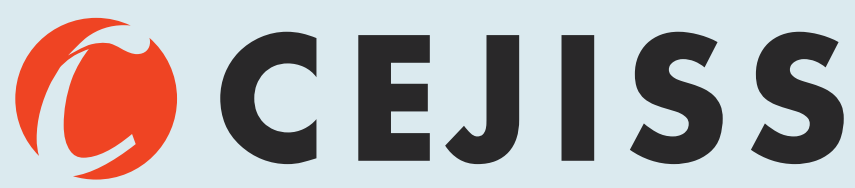

CENTRAL EUROPEAN JOURNAL OF INTERNATIONAL AND SECURITY STUDIES

$3 \cdot 2016$

\title{
End of Democracy?
}

Special Report on Democratisation in Romania 
contentious issue and, given the opacity of the Chinese regime, unlikely to be fully resolved (or resolvable).

According to Harris, cyber warfare is one domain where China is actively seeking superiority, based on both contemporary experience CEJISS and foreign policy. It is the assumption of the Chinese administration 3/20I6 that cyber warfare is key to future conflicts, and will possibly be the only platform upon which conflict takes place. As such, the modernisation and integration of information technology systems to China's war-fighting capability is integral not only to China's foreign policy, but to its national security. Harris sees conventional weaponry, a significant part of China's military upgrade and modernisation process, as a partial response to the American 'pivot' toward Asia, as well as a response to naval and territorial disputes of both historical and contemporary times. Harris' interpretation of China's slow approach to achieving parity in conventional weaponry is that the Chinese have recognised that it will take years, possibly decades, to achieve parity with the us and so have invested more time and resources into informatised, or asymmetric, warfare capabilities. This is all possible due to the massive, and growing, strength of the Chinese economy. Despite the slowdown of economic growth in the past several years, China has enormous economic resources at its command, including a significant portion of the us' national debt. While it may seek to influence the international system slowly, and as part of the system, rather than a challenger, Harris notes that China has a marked interest in the stability of the current system.

Given the historical opacity of China's foreign policy, and government in general, Harris has produced a work notable for its readability and its informative nature. It has clearly been meticulously researched, and Harris' depth of knowledge of the subject matter is evident in every chapter. His style of writing is suitable for academic, civilian and professional audiences. Not only is it eminently readable, but China's Foreign Policy should be commended for the depth of its analysis, considering the difficulty of the subject. It should be considered a crucial text for anyone interested in the evolution of Chinese foreign policy. 


\section{Russian Foreign Policy}

\section{The Return of Great Power Politics}

Reviewed by Alireza Salehi Nejad

In Russian Foreign Policy: The Return of Great Power Politics, Jeffrey Mankoff examines the course of Russian foreign policy since the dissolution of the Soviet Union in I99I. He provides a comprehensive overview of both the continuity and the changes in Russian foreign policy from the end of the Cold War to the Putin era, and analyses Russia's interactions with major global powers. Throughout the book, the author makes use of various theoretical approaches, including theories of international relations, classical geopolitical theory and Russian geopolitical tradition.

Mankoff argues that Russia's more assertive behaviour since Vladimir Putin became president in 2000, is the result of two things: I) a deep-seated consensus among the country's elite about Russia's identity and interests; and 2) a favourable convergence of events such as the persistence of high energy prices and the check on us power resulting from the wars in Iraq and Afghanistan.

Presenting an even-handed treatment of controversial issues, Mankoff analyses Russia's interactions with major global actors, including the United States, the European Union, the Commonwealth of Independent States and China. Despite Moscow's harsh rhetoric and the deployment of Russian forces against Georgia in 2008, the author convincingly demonstrates that there is little reason to fear a return to a Cold War-like standoff with the West.

According to Mankoff, 'the substance of disputes between Moscow and Washington today looks much like that of the I990s, Russian leaders resent being ignored, while the us fears Russian attempts to 
overturn the post-Cold War status quo' (p. 99). He argues that, rather than directly challenging the West, today's Russia is more interested in restoring what its leaders consider to be its rightful place among the world's major powers. The impulse behind the recent assertiveCEIISS ness of Russia's foreign policy is not new, and can be traced back to 3/20I6 the Yeltsin era, when Russian leaders abandoned a liberal, pro-Western orientation and committed themselves to re-establishing Russia as a great power. High oil prices and the restoration of a firm political hand have added fuel to the fire. Even if circumstances change or evolve, the impulse is here to stay.

Within this framework, Mankoff explores in detail the ups and downs in us-Russian relations, Russia's complex interactions with Europe, its relations with Asia, and its dealings with its post-Soviet neighbours. As a result of this analysis he claims that Russia's foreign policy, particularly its relations with Europe, China and the countries of the former Soviet Union 'can be understood only in the context of Moscow's strategy for dealing with Washington' (p. I03). In the author's view, 'what was therefore notable about Putin's approach was the degree to which he emphasized the maintenance of a basically positive relationship with the us, even at the cost of unpopular sacrifices' (p. IOI).

Mankoff concludes that Russia should be treated just like any other large non-Western state such as China, India, South Africa, Brazil, Mexico or Pakistan. These countries might frequently present a significant challenge, but cooperation with them is both possible and necessary. Unfortunately, because of the habit of thinking about Russia in terms of the bygone Cold War, it has been much harder for the West to work out a new framework for dealing with a Moscow that is neither a foe nor an ally (p. 306). All in all, this book is a valuable contribution to the ongoing international debate about Russia's international position, increasingly significant when considering recent developments in Ukraine. 